\title{
The Challenge of Learning Ethics as a Medical Student: Synthetic Ethics as a New Approach
}

LIAM BUTCHART (D)

*Author affiliations can be found in the back matter of this article
凹

Levy

Library

Press

\section{ABSTRACT}

Over the past few decades, medical school curricula have grown to include bioethics courses, recognizing the importance of ethical clinical practice [1, 2, 3]. As a medical student, I have found that one of the most difficult ethical challenges for myself and others during training has been simply learning bioethics. This project examines some of the issues I have seen in bioethics education, which stymie both knowledge uptake by students and the application of moral thought in day-to-day practice; it then suggests a new approach to teaching bioethics, one founded in what I call "synthetic ethics" - being able to engage in moral reasoning that is vibrant and flexible, rather than dogmatic and unexamined, using the challenges posed by COVID-19 as a case study.

I outline three general issues in bioethics pedagogy that curtail students' ability to engage in synthetic ethics, informed by both my own experience and the existing literature: 1) teachers not challenging personal subjectivism, which fails to inculcate students with the moral character they need as physicians [4]; 2) espousal of the hard, intransigent deontology of some faculty and the AMA [5, 6]; and 3) the cavalier disinterest of many students towards the humanities [7]. This is all in the context of our pluralistic society, which makes approaching ethical quandaries even more complex and challenging for many non-philosophers; if pluralism is abandoned for ethical absolutism, we run the risk of ethical imperialism [8].

The need for effective bioethical thought is demonstrated by scenarios like the COVID pandemic: resources are stretched and the disease is global - and the bioethical establishment provides solutions that are unsatisfying, pitting basic principles against each other with no resolution $[9,10]$. This is where synthetic ethics becomes really necessary: it allows us to balance different cultural and moral considerations to find new solutions that are better for patients and providers. By engaging with synthetic

CORRESPONDING AUTHOR:

\section{Liam Butchart}

Renaissance School of Medicine, Stony Brook University, US

liam.butchart@ stonybrookmedicine.edu

\section{KEYWORDS:}

Bioethics; medical education; deontology; Hegel

\section{TO CITE THIS ARTICLE:}

Butchart L. The Challenge of Learning Ethics as a Medical Student: Synthetic Ethics as a New Approach. ISMMS Journal of Science and Medicine. 2021; 1(1): 7, pp. 1-3. DOI: https:// doi.org/10.29024/ijsm.36 
ethics - adopting a Hegelian approach (Figure 1) to resolving theoretical tensions and being willing to bracket out overly-deontological values - we can combine disparate theories or their component parts, allowing us to better address these issues and come up with new solutions.

\section{Hegelian Dialectic}

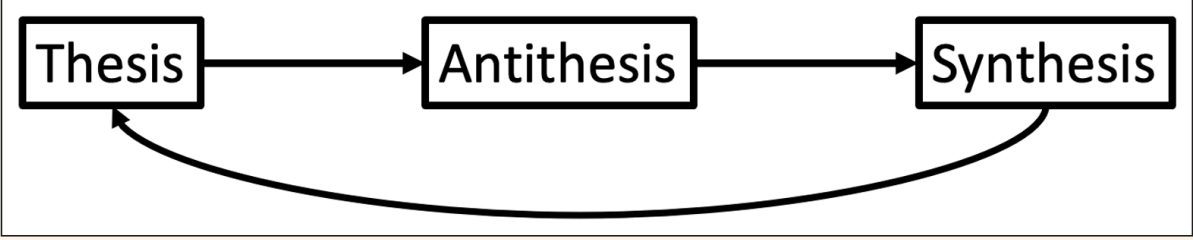

I close with a few thoughts on implementation of synthetic ethics: more rigorous teaching of basic ethical theories, emphasizing innovation and out-of-the-box thinking, utilizing stimulating case studies and being willing to move to pass/fail grading all are possible ways to incorporate synthetic ethics training into medical school coursework. By doing so, we will develop the faculties that physicians need to address the problems that will inevitably arise during our careers.

\section{COMPETING INTERESTS}

The author has no competing interests to declare.

\section{AUTHOR AFFILIATION}

Liam Butchart (D) orcid.org/0000-0002-2353-8976

Renaissance School of Medicine, Stony Brook University, US

\section{REFERENCES}

1. American Medical Association. "AMA Code of Medical Ethics: AMA Principles of Medical Ethics." 2016. https://www.ama-assn.org/sites/ama-assn.org/files/corp/media-browser/principles-of-medical-ethics.pdf.

2. Self D, Baldwin DW, Jr., Olivarez M. "Teaching Medical Ethics to First-year Students by Using Film Discussion to Develop Their Moral Reasoning.” Academic Medicine. 1993; 68(5): 383-385. DOI: https:// doi.org/10.1097/00001888-199305000-00025

3. Roff S, Preece P. "Helping medical students to find their moral compasses: ethics teaching for second and third year undergraduates." Journal of Medical Ethics. 2004; 30(5): 487-489. DOI: https:// doi.org/10.1136/jme.2003.003483

4. Calman KC, Downie RS. "Practical problems in the teaching of ethics to medical students." Journal of Medical Ethics. 1987; 13: 153-156. DOI: https://doi.org/10.1136/jme.13.3.153

5. Foster C. "Autonomy should chair, not rule." The Lancet. 2010; 275(9712): 368-369. DOI: https://doi. org/10.1016/S0140-6736(10)60156-0

6. American Medical Association. AMA Code of Ethics: Chapter 2: Opinions on Consent, Communication and Decision Making. https://www.ama-assn.org/system/files/2019-06/code-of-medical-ethicschapter-2.pdf.

7. Liu Y, Erath A, Salwi S, Sherry A, Mitchell M. "Alignment of Ethics Curricula in Medical Education: A Student Perspective." Teaching and Learning in Medicine. 2020; 32(3): 345-351. DOI: https://doi.org/1 0.1080/10401334.2020.1717959

8. Glick S. "The teaching of medical ethics to medical students." Journal of Medical Ethics. 1994; 20: 239-243. DOI: https://doi.org/10.1136/jme.20.4.239

9. Emanuel E, et al. "Fair Allocation of Scarce Resources in the Time of Covid-19." New England Journal of Medicine. 2020; 382: 2049-2055. DOI: https://doi.org/10.1056/NEJMsb2005114

10. Savulescu J, Persson I, Wilkinson D. "Utilitarianism and the pandemic." Bioethics. 2020; 34(6): 620-632. DOI: https://doi.org/10.1111/bioe.12771 
ISMMS Journal of Science

and Medicine

DOI: $10.29024 /$ ijsm. 36

TO CITE THIS ARTICLE:

Butchart L. The Challenge of Learning Ethics as a Medical

Student: Synthetic Ethics as a New Approach. ISMMS Journal of Science and Medicine. 2021; 1(1): 7, pp. 1-3. DOI: https:// doi.org/10.29024/ijsm.36

Submitted: 16 December 2020 Accepted: 16 December 2020

Published: 22 January 2021

COPYRIGHT:

(C) 2021 The Author(s). This is an open-access article distributed under the terms of the Creative Commons Attribution 4.0 International License (CC-BY 4.0), which permits unrestricted use, distribution, and reproduction in any medium, provided the original author and source are credited. See http://creativecommons.org/ licenses/by/4.0/.

ISMMS Journal of Science and Medicine is a peer-reviewed open access journal published by Levy Library Press. 